\title{
Electrochemical Corrosion Behavior of as-cast Zn-rich Zn-Mg Alloys in a 0.06M NaCl Solution
}

\author{
Talita A. Vida ${ }^{1}$,Emmanuelle S. Freitas ${ }^{1}$, Noé Cheung ${ }^{1}$, Amauri Garcia ${ }^{1}$, Wislei R. Osório ${ }^{2,3, *}$ \\ ${ }^{1}$ Department of Manufacturing and Materials Engineering, University of Campinas, UNICAMP, \\ 13083-860, Campinas, SP, Brazil \\ ${ }^{2}$ School of Applied Sciences / FCA, Research Group in Manufacturing Advanced Materials, \\ University of Campinas, UNICAMP, Limeira, SP, Brazil \\ ${ }^{3}$ School of Technology, University of Campinas-UNICAMP, Limeira, SP 13484-332, Brazil \\ *E-mail: wislei.osorio@fca.unicamp.br
}

doi: $10.20964 / 2017.06 .37$

Received: 1 March 2017 / Accepted: 23 April 2017 / Published: 12 May 2017

The electrochemical corrosion behavior of as-cast samples of $\mathrm{Zn}-1.2 \mathrm{wt} . \%$ and $\mathrm{Zn}-2.0 \mathrm{wt} . \% \mathrm{Mg}$ alloys, solidified under similar cooling rates, is investigated in the present study. A stagnant and naturally aerated $0.06 \mathrm{M} \mathrm{NaCl}$ solution at $25^{\circ} \mathrm{C}$ was used in the corrosion tests. In order to evaluate the corrosion resistance, electrochemical impedance spectroscopy (EIS) plots, potentiodynamic polarization curves and an equivalent circuit are used. It is found that the increase in the alloy $\mathrm{Mg}$ content (from $1.2 \mathrm{wt} . \%$ to $2.0 \mathrm{wt} . \%$ ) refines both the $\mathrm{Zn}$-rich dendritic matrix and the eutectic mixture and decreases the volume fraction of the Zn-rich phase. Consequently, this is shown to affect the cathode-to-anode area ratio, which decreases affecting the corrosion behavior. The experimental corrosion parameters demonstrated that the $\mathrm{Mg}$ content is associated with susceptibility to pitting corrosion.

Keywords: Zn-Mg alloys; solidification; microstructure; impedance; polarization.

\section{FULL TEXT}

(C) 2017 The Authors. Published by ESG (www.electrochemsci.org). This article is an open access article distributed under the terms and conditions of the Creative Commons Attribution license (http://creativecommons.org/licenses/by/4.0/). 